\title{
In Vitro Macroscopic and Endoscopic Analysis of Three- Rooted Maxillary Premolars and Two-Rooted Mandibular Premolars in the Same Individual: a Case Report
}

\author{
Análisis Macroscópico y Endoscópico In Vitro de Premolares Maxilares Trirradiculares y \\ Mandibulares Birradiculares en un Mismo Individuo: un Reporte de Caso \\ "Daniel Aracena; *,**Victor Beltrán; *Ramón Fuentes \& *,****Eduardo Borie
}

ARACENA, D.; BELTRÁN, V.; FUENTES, R. \& BORIE, E. In vitro macroscopic and endoscopic analysis of three-rooted maxillary premolars and two-rooted mandibular premolars in the same individual: a case report. Int. J. Morphol., 30(1):19-24, 2012.

SUMMARY: The recent addition of endoscopy in dental practice has enabled clinicians to have an excellent view of the operative field, yielding highly successful visualization of anatomical structures that are difficult to access, both in oral surgery and endodontics. The purpose of this report is to provide an in vitro macroscopic, radiographic, and endoscopic description of the anatomic variation of the roots of maxillary and mandibular first premolars in the same patient. A 22-year-old patient was referred by an orthodontist for the extraction of all the first premolars. Once extracted, the premolars were examined macroscopically and then analyzed radiographically after trepanation and filled root canal systems. Subsequently, a diaphanization process was carried out and the samples were sectioned at the middle and apical third for observation by endoscope. It was found that both the maxillary first premolars had three roots, and mandibular first premolars had two roots, all with complete root formation. Apical deltas or accessory canals were not identified in the radiographic images; however, through endoscope at the middle third, it was possible to observe an accessory canal to the first maxillary and mandibular right premolars. Thus, it can be concluded that the view through the endoscope allows better identification of accessory canals than X-rays.

KEY WORDS: Premolars; Tooth roots; Root canal; Endoscopy.

\section{INTRODUCTION}

Proper maintenance of anatomical and physiological integrity of the periapical structures can be established entirely from adequate knowledge of the normal characteristics of the teeth and their anatomical variations. It is essential to view and know the internal and external anatomy of the teeth before carrying out a correct endodontic therapy (Vertucci \& Gegauff, 1979; Barbosa et al., 2009), which is essential to identify specific elements for a successful management in cases of teeth with unusual root canal morphology (Barbosa et al.).

Clinically, one must be very careful when performing endodontic treatment of maxillary premolars because of the extreme variability in its anatomy (Cantatore et al., 2009). There are various theories explaining the existence of abnormal number of roots (greater than normal), including hyperactivity of the Hertwig's epithelial root sheath (Holtzman, 1997) and a pathological degeneration in the same area, producing an invagination from the dental papi- 1la forming an accessory root (Roig \& Morelló, 2006). Usually, the first premolars have a high variability in the morphology of the root canal system, but the presence of three roots is very rare (Javidi et al., 2008).

Each year, new materials and tools are introduced to the dental market with the aim of obtaining more reliable treatments. The root canal preparation has been simplified and optimized with innovations in rotary instrumentation and root-filling methods; however, the complexity related to the treatment of teeth with anatomical variations makes the therapeutic prognosis difficult.

In this sense, the recent addition of endoscopy in the dental practice has enabled the clinicians to have an excellent view of the operative field, yielding highly successful periapical surgery (Taschieri et al., 2008; Moshonov et al., 2009) and visualization of anatomical structures that are difficult to access, both in oral surgery and endodontic

* Departamento de Odontología Integral, Universidad de La Frontera, Temuco, Chile.

** Alumno del programa de Magister en Odontología, Universidad de La Frontera, Temuco, Chile.

${ }^{* * * *}$ Post-Graduate Student, Department of Dental Materials and Prosthodontics, Dental School of Ribeirão Preto, University of São Paulo, Ribeirão Preto, SP, Brazil. 
treatment (Held et al., 1996; Engelke \& Galle, 2008; Taschieri et al.; Beltrán et al., 2011). von Arx et al. (2011) successfully used the endoscope for the visualization of fracture lines in root segments extracted by peri-radicular surgery.

The purpose of this report is to provide an in vitro macroscopic, radiographic, and endoscopic description of anatomic variables in the roots of the maxillary and mandibular first premolars in a patient in relation to the atypical distribution of root canals and the presence of accessory canals and apical deltas into the root canal system in serial cross-sections using a combined technique of diaphanization and endoscopic visualization by immersion technique, and comparing the radiographic findings with endoscopy.

\section{CASE REPORT}

A 22-year-old Chilean patient visited a dental control for a routine examination. The patient was referred by an orthodontist, who suggested extraction of the maxillary and mandibular first premolars. The extra-oral examination showed no abnormalities, and the intraoral investigation did not reveal the presence of caries and periodontal disease. Among the complementary tests that were requested, a panoramic radiograph was taken with plaster casts for the maxilla and mandible. After the tooth extraction procedure, we observed each of these teeth macroscopically. The extracted teeth were cleaned and a periapical radiograph was taken for each tooth (Figs. 1. A1-A4).

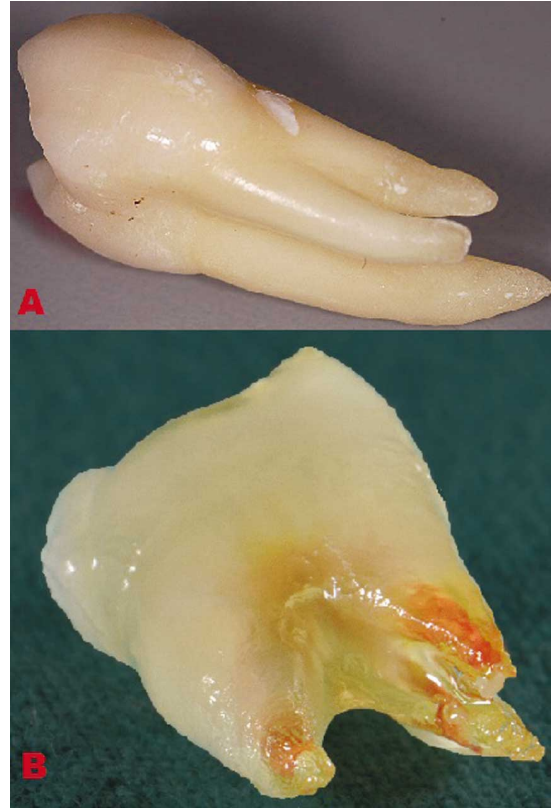

Fig. 2. A. Upper left first premolar without diaphanized. B. After Diaphanisation.

Later, the teeth were drilled and root instrumentation was performed with the balanced force technique. Finally, root canal filling using gutta percha thermoplasticized technique with a Calamus Dual 1300 Obturation System (Dentsply Maillefer, Woodinville, Washington, USA) was performed (Figs. 1. B1-B4).

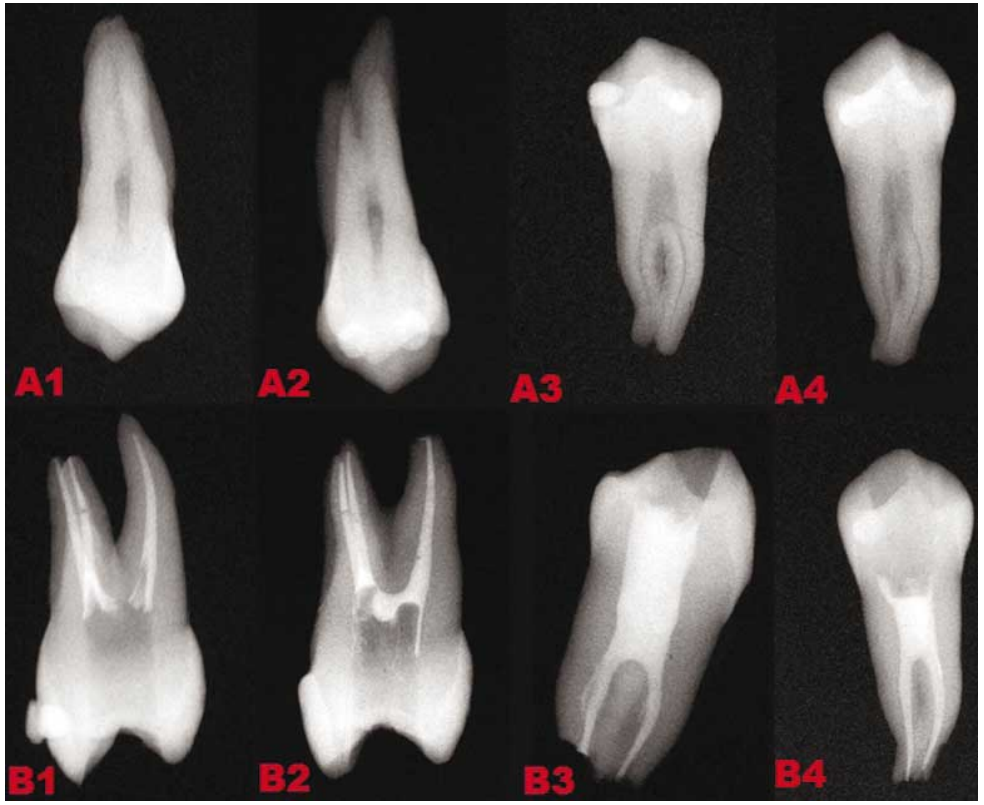

Fig. 1.A1-A4: Periapical initial radiographs of first three-rooted maxillary premolars and two-rooted mandibular premolars. B1-B4: Periapical radiographs after the root filling. Note that after the root canal filling can be perfectly distinguished according to the number of teeth observed, however, there are no accessory canals.
The teeth were subjected to a process called diaphanization that makes the teeth transparent to macroscopically observe the teeth extracted and endoscopically examine the distribution of root canals and possible location of apical deltas and accessory canals (Fig. 2B). For this, the teeth were immersed in $7 \%$ hydrochloric acid for 48 hours for decalcification. Subsequently, they were immersed in $70 \%$ alcohol for 5 hours, $80 \%$ alcohol 5 hours, 96\% alcohol 5 hours, and 100\% alcohol 5 hours to dehydrate the teeth. Later, the teeth were immersed in methyl salicylate, completing the diaphanization process in 24-48 hours (Paredes et al., 1993; Lozano et al., 2004).

In each root, a serial cross-section through a scalpel was performed, because the diaphanized teeth have a lower degree of hardness than a normal tooth. The cuts were made at apical ( $2 \mathrm{~mm}$ from the apex) and middle (5 $\mathrm{mm}$ from the apex) part of each root, thus obtaining a portion of each site. The combination 
of diaphanization and endoscopic view by using immersion technique (Engelke, 2002) applied to the root cross-sections allowed us to assess the presence of accessory canals and apical deltas directly through an endoscope Karl Storz NTSC TELE PACK 20043120 (Tuttlingen, USA), with a 1.9-mm optic with rigid support and continuous internal irrigation of saline solution. Photographs of the radiographs were taken prior to root canal treatment, during the endodontic procedure, and when diaphanized, with a Nikon D90 SLR camera with a Micro-Nikkor lens $105 \mathrm{~mm}$ system with a Wireless Remote Speedlight SB-R200.

Radiographic evaluation of the patient revealed no evidence of any abnormalities in shape or root structure in panoramic radiography. Macroscopic observation of the extracted teeth showed that both first maxillary premolars had three roots and mandibular had two roots, all with complete root formation (Figs. 2A and 3).

In periapical radiographs of the extracted teeth, the number of roots or canals in the maxillary premolars could not be clearly observed; however, after the filling of root canals, it became evident that the first maxillary premolars had three canals, while mandibular had two canals. Remarkably, apical deltas or accessory canals could not be identified in the radiographic images. However, using the endoscope and diaphanization, at the middle third, an accessory canal to the right maxillary and mandibular premolars was observed (Figs. 4A and 4B) - a situation that could not be identified radiographically.

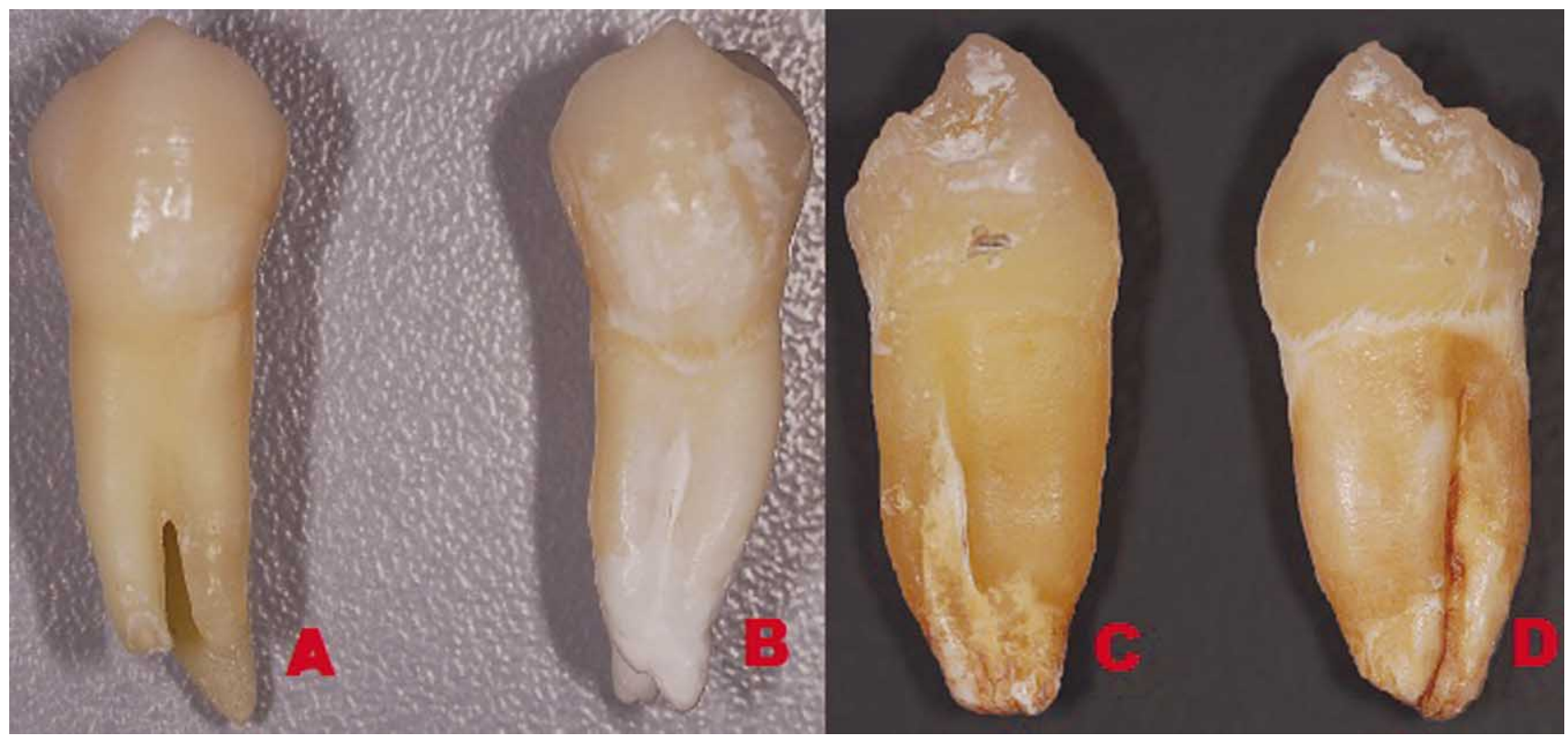

Fig. 3. First three-rooted maxillary premolars and two-rooted mandibular premolars. A. Tooth 1.4; B. Tooth 2.4; C. Tooth 4.4, D. Tooth 3.4.

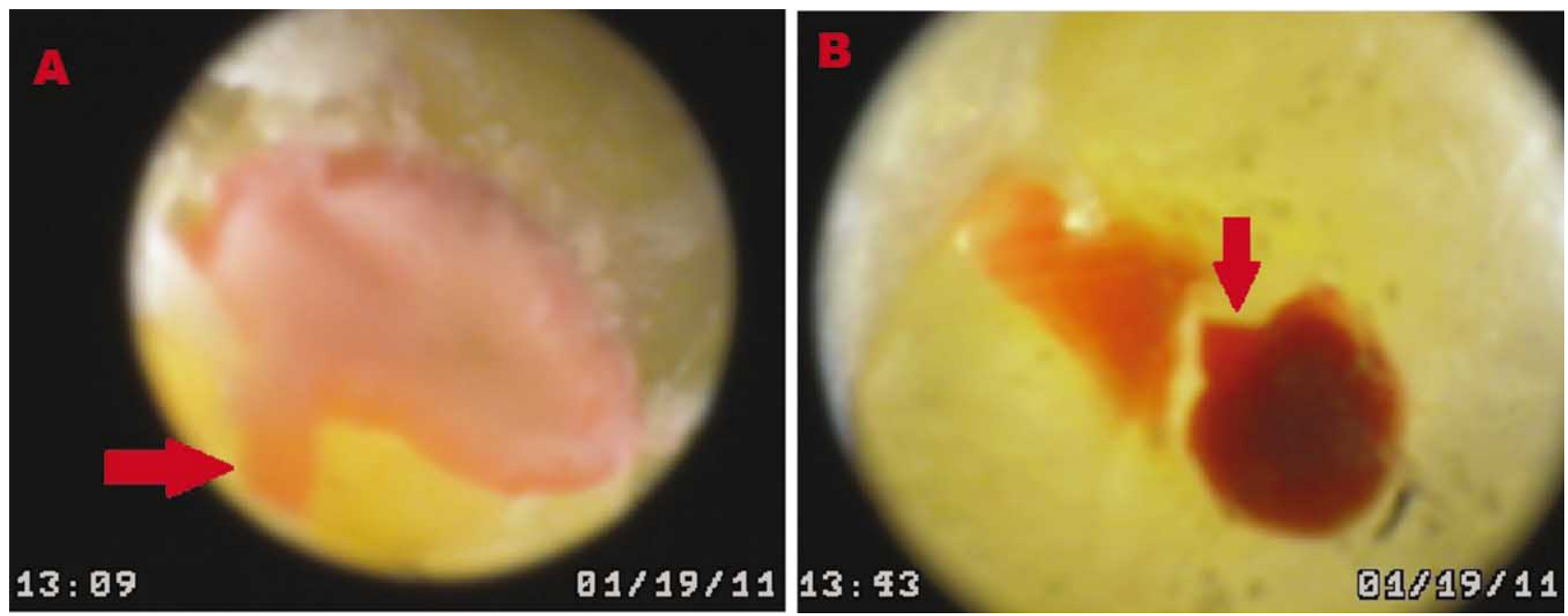

Fig. 4. Accesory canals visualized with endoscope by immersion technique in cross-sections at middle third level of the diaphanized teeth (red arrow). 


\section{DISCUSSION}

The knowledge required in dentistry involves the proper understanding of the molecular biological principles as well as the anatomical and physiological characteristics regarding the pathogenesis of the disease. Anatomy, histology, and embryology are the basic disciplines of great importance in clinical application; so for understanding and retention, we should use all available resources (Suazo et al., 2008). In this context, the International Dental Federation recommends that any dental surgical competence should have solid biological, physiological, and anatomical knowledge to accurately complete a procedure.

It is important to consider the changes in the morphology of teeth with pathologies that require root canal treatment or other procedures within the duct system (D'Arcangelo et al., 2001; Evans 2004). In this sense, Chaparro et al. (1999) and Cleghorn et al. (2007) emphasize the importance of thorough knowledge of tooth morphology and careful radiographic examination of the teeth before establishing an endodontic therapy.

Studies on the morphology of maxillary first premolar with three roots and three canals show that the reported incidence varies between 0.5 and 6\% (Bellizi \& Hartwell, 1985; Evans; Javidi et al.). Usually, a tooth has a single canal in each of its roots (Vertucci \& Gegauff). Other authors have found that the prevalence of three canals in the first premolars corresponds to $2.5-5 \%$ of the cases (Awawdeh et al., 2008). According to Tzanetakis et al. (2007), the incidence of two or more canals in the mandibular second premolars may occur in a range of $1.2-34 \%$ of the cases.

The presence of three canals in a mandibular second premolar, with one lingual canal and two vestibular canals, has been reported in 0 (Vertucci \& Gegauff) and $0.4 \%$ (Zillich \& Dawson, 1973) of the cases, respectively. In a study of 6700 mandibular first premolars, $98 \%$ of the teeth presented one root, while the incidence of two roots was $1.8 \%$ and three roots was $0.2 \%$. At the same time, $75.8 \%$ were found to have one canal, and $24.2 \%$ had two or more. In addition, $78.9 \%$ of the roots had a single apical foramen and $21.1 \%$ had two or more foramina (Cleghom et al.).

Another study based on computer tomography (CT) examining the morphology of the root canal of the mandibular first premolar teeth extracted from 100 people in India found a single canal in $80 \%$ of the cases, two canals in $11 \%$ of the cases, and canal with $\mathrm{C}$ shape in $2 \%$ of the cases (Sandhya et al., 2010). Moreover, Atieth (2008) reported a prevalence of maxillary premolars with three roots in $1.2 \%$ of the Saudi population. Similarly, Chaparro et al., reported 3.3\% prevalence in Andalusian population. Furthermore, a study that examined 6700 teeth found an incidence of $1.8 \%$ of first premolars with two roots, of which $24 \%$ of the cases had two or more canals and $21.1 \%$ had two apical foramina (Cleghorn et al.).

There is no report in the literature on patients having supernumerary roots in the four first premolars. In addition, most of the root canal treatments are guided by radiographic examination, and the present study has shown that it is not totally reliable, and that accessory canals could be identified through the endoscopic technique (Figures 4a and 4B), not radiologically.

According to Taschieri et al., the use of high magnification devices in dentistry to improve the quality of treatment is becoming increasingly common. Thus, the use of intraoperative and postoperative magnification, either with a microscope or endoscope, greatly facilitates the way to achieve success in various dental treatments and improve prognosis in the treatment of anatomic variants. However, to determine the sensitivity of each of these devices, more studies addressing the intraoperative combination of these devices with various current therapies are needed.

The knowledge of normal root canal anatomy and their variations is essential to minimize the possibility of occurrence of accidents during the development of dental treatments. This case report highlights the importance of complete knowledge about the morphology of root canals and their possible variations, complementing the clinical examination with radiographic investigation, to increase the capacity of treating difficult cases during the clinical approach. Finally, the view through the endoscope, if it is possible to use clinically, allows better identification of accessory canals than X-rays.

ACKNOWLEDGMENT. We appreciate the assistance of Dr. Rodrigo Gayán in digitizing the images.

ARACENA, D.; BELTRÁN, V.; FUENTES, R. \& BORIE, E. Análisis macroscópico y endoscópico in vitro de premolares maxilares trirradiculares y mandibulares birradiculares en un mismo individuo: un reporte de caso. Int. J. Morphol., 30(1):19-24, 2012.

RESUMEN: La reciente incorporación del endoscopio a la práctica odontológica ha permitido al clínico, contar con una excelente visualización del campo operatorio, consiguiendo resultados altamente exitosos en la visualización de estructuras anatómicas de difícil acceso, tanto en cirugía oral como en endodoncia. El propósito de este reporte de caso es realizar una 
descripción in vitro macroscópica, radiográfica y endoscópica de las variables anatómicas de las raíces de los primeros premolares maxilares y mandibulares en un mismo paciente. Una paciente de 22 años es derivada por un ortodoncista para exodoncia de los primeros premolares. Una vez extraídos, los premolares fueron analizados en un principio macroscópicamente, para luego ser analizados radiográficamente una vez trepanados y obturados los sistemas de conductos radiculares. Posterior a esto, se sometieron a un proceso de diafanización y se les realizaron cortes a nivel del tercio apical y medio para ser observados mediante endoscopio. Se detectó que ambos primeros premolares superiores presentaban 3 raíces, y los inferiores 2 raíces, todos con formación radicular completa. No se identificaron deltas apicales ni conductos accesorios en las imágenes radiográficas; sin embargo, fue posible mediante el endoscopio a nivel del tercio medio, un conducto accesorio para los primeros premolares derechos inferiores y superiores situación que no se pudo identificar radiográficamente. Finalmente, la visualización a través del endoscopio permite una mejor identificación de conductos accesorios que las radiografías.

PALABRAS CLAVE: Premolares; Raíces dentales; Canales radiculares; Endoscopía.

\section{REFERENCES}

Atieth, M. A. Root and canal morphology of maxillary first premolars in a Saudi population. J. Contemp. Dent. Pract., 9(1): 46-53, 2008.

Awawdeh, L.; Abdullah, H. \& Al-Qudah, A. Root form and canal morphology of Jordanian maxillary first premolars. J. Endod., 34(8):956-61, 2008.

Barbosa, F. O.; Gusman, H. \& Pimenta de Araújo, M. C. A comparative study on the frequency, location, and direction of accessory canals filled with the hydraulic vertical condensation and continuous wave of condensation techniques. J. Endod., 35(3):397-400, 2009.

Bellizi, R. \& Hartwell, G. Radiographic evaluation of root canal anatomy of in vivo endodontically treated maxillary premolars. J. Endod., 11(1):37-9, 1985.

Beltrán, V.; Cantín, M.; Fuentes, R. \& Engelke, W. Bilateral Presence of Mandibular Incisive Canal. An Anatomical Structure with Clinical Relevance. Int. J. Morphol., 29(2):5439, 2011.

Cantatore, G.; Berutti, E. \& Castellucci, A. Missed anatomy: frequency and clinical impact. Endod. Topics, 15(1):3-31, 2009.

Chaparro, A. J.; Segura, J. J.; Guerrero, E.; Jiménez-Rubio, A.; Murillo, C. \& Feito, J. J. Number of root and canals in maxillary first premolars: study of an Andalusian population. Endod. Dent. Traumatol., 15(2):65-7, 1999.
Cleghorn, B. M.; Christie, W. H. \& Dong, C. C. The root and root canal morphology of the human mandibular first premolar: a literature review. J. Endod., 33(5):509-16, 2007.

D'Arcangelo, C.; Varvara, G. \& De Fazio, P. Root canal treatment in mandibular canines with two roots: a report of two cases. Int. Endod. J., 34(4):331-4, 2001.

Engelke, W. G. In situ examination of implant sites with support immersion endoscopy. Int. J. Oral Maxillofac. Implants., 17(5):703-6, 2002.

Engelke, W. \& Galle, C. Endoscopic Interventions in Oral Implantology - A Report of 5 Years Clinical Experience. Int. J. Odontostomat., 2(2):153-61, 2008.

Evans, M. Combined Endodontic And Surgical Treatment Of A Three-rooted Maxillary First Premolar. Aust. Endod. J., 30(2):53-5, 2004.

Held, S. A.; Kao, Y. H. \& Wells, D. W. Endoscope--an endodontic application. J. Endod., 22(6):327-9, 1996.

Holtzman, L. Root canal treatment of a mandibular canine with three root canals. Case report. Int. Endod. J., 30(4):291-3, 1997.

Javidi, M.; Zarei, M. \& Vatanpour, M. Endodontic treatment of a radiculous maxillary premolar: a case report. J. Oral Sci., 50(1):99-102, 2008.

Lozano, A.; Forner, L.; Llena, M.C. Estudio in vitro de la anatomía del sistema de conductos radiculares con radiología convencional y digital. Endodoncia, 22(4):236-43, 2004.

Moshonov, J.; Michaeli, E. \& Nahlieli, O. Endoscopic root canal treatment. Quintessence Int., 40(9):739-44, 2009.

Paredes, J.; Howard, A. \& Guizar, C. A. Diafanización dental, una alternativa por la enseñanza preclínica en endodoncia. Práctica Odontológica, 14(9): 9-10, 1993.

Roig, M. \& Morelló, S. Introducción a la patología dentaria. Parte 1. Anomalías dentarias. Rev. Oper. Dent. Endod., 5:51, 2006.

Sandhya, R.; Natanasabapathy, V. \& Kandaswamy, D. Assessment of root canal morphology of mandibular first premolars in the Indian population using spiral computed tomography: An in vitro study. Indian J. Dent. Res., 21(2):169-73, 2010.

Suazo, I.; Cantín, M.; Bustos, I. \& Salgado, G. Teaching of the integrated morphology. Int. J. Morphol., 26(1):127-30, 2008.

Taschieri, S.; Del Fabbro, M.; Testori, T. \& Weinstein, R. Microscope versus endoscope in root-end management: a randomized controlled study. Int. J. Oral Maxillofac. Surg., 37(11):1022-6, 2008. 
ARACENA, D.; BELTRÁN, V.; FUENTES, R. \& BORIE, E. In vitro macroscopic and endoscopic analysis of three-rooted maxillary premolars and two-rooted mandibular premolars in the same individual: a case report. Int. J. Morphol., 30(1):19-24, 2012.

Tzanetakis, G. N.; Lagoudakos, T. A. \& Kontakiotis, E. G. Endodontic Treatment of a Mandibular Second Premolar with Four Canals Using Operating Microscope. J. Endod., $33(3): 318-21,2007$

Vertucci, F. J. \& Gegauff, A. Root canal morphology of the maxillary first premolar. J. Am. Dent. Assoc., 99(2):194-8, 1979.

von Arx, T.; Steiner, R. G. \& Tay, F. R. Apical surgery: endoscopic findings at the resection level of 168 consecutively treated roots. Int. Endod. J., 44(4): 290-302, 2011.

Zillich, R. \& Dowson, J. Root canal morphology of mandibular first and second premolars. Oral Surg. Oral Med. Oral Pathol., 36(5):738-44, 1973
Correspondence to:

Daniel Aracena Rojas

Depto. Odontología Integral

Facultad de Medicina

Universidad de La Frontera

Manuel Montt 112

Temuco-CHILE

Email: saracena@ufro.cl

Received: 28-08-2011

Accepted: 21-11-2011 